\title{
Populism in Europe: An Illiberal Democratic Response to Undemocratic Liberalism (The Government and Opposition/Leonard Schapiro Lecture 2019)
}

\author{
Cas Mudde \\ Department of International Affairs, University of Georgia, Athens, GA, US \\ Corresponding author. Email: mudde@uga.edu
}

(Received 12 February 2021; revised 1 April 2021; accepted 13 April 2021;

first published online 7 June 2021)

\begin{abstract}
In this lecture, I lay out my approach to populism, which falls within the now dominant 'ideational approach' of populism, discuss the complex relationship between populism and politics, and identify some of the main causes of the ongoing 'populist Zeitgeist'. My main arguments are: (1) while populism is related to (real and perceived) 'crises', these so-called 'crises' are often catalysts rather than prime causes of the rise of populism; (2) populism is essentially an illiberal democratic response to undemocratic liberalism; and (3) populism can only be overcome by more rather than less liberal democracy. I illustrate my arguments on the basis of the recent rise of populism in Europe, but believe they also largely hold true beyond that specific regional and temporal context.
\end{abstract}

Keywords: populism; political parties; liberal democracy; Europe

Allow me to start this lecture with a personal anecdote that is directly related to this lecture, and to the article that started it all, 'The Populist Zeitgeist', published in this journal more than 15 years ago now (Mudde 2004). I had been studying the far right for a few years and was working on $\mathrm{my} \mathrm{PhD}$, when I started thinking about the term populism, as it was becoming more used, in particular because of the ground-breaking work of Hans-Georg Betz (1994). Still, I was not overly convinced by his functionalist definition, focused heavily on the 'instrumentalization' of 'resentment'. So, I tried to look for some other people and, in the end, I went to Margaret Canovan (1981), whose work has been very influential within populism studies, even though she never really clearly defined the concept. Which brought me to the work of Ernesto Laclau. I read, or thought I read, his 1977 book Politics and Ideology in Marxist Theory: Capitalism - Fascism Populism, but just could not make head nor tail of it (Laclau 1977). I had no clue what he was writing and, after accepting intellectual defeat, decided not to use the term populism, as, clearly, I was not smart enough to grasp its meaning. 
Little changed until I moved to the University of Antwerp, where I co-supervised a graduate student, Jan Jagers, who was working on a $\mathrm{PhD}$ on populism within Flemish parties (Jagers 2006). We had many discussions about populism, developing separate, if overlapping, conceptualizations of it. One day, I went back to Leiden University, my alma mater, and met up with my former $\mathrm{PhD}$ supervisor, the late great Peter Mair. I told him, 'So, I've been thinking about populism lately, and I think we live in a populist Zeitgeist.' He almost jumped up and said, 'Populist Zeitgeist, that's perfect, write an article about that.' I responded that I only had a definition of populism and a general idea of a populist Zeitgeist at the moment, but he insisted I write an article. 'With a title like that, it will be cited a lot', he said, which turned out to be true. Although, interestingly, it was not cited that much in the first 10 years and only really took off more recently, in particular since the annus horriblis 2016, in which Brexit and Trump shocked the world, and 'populism studies' exploded (Rovira Kaltwasser et al. 2017a).

In this lecture I want to lay out my own approach to populism, which falls within the now dominant 'ideational approach' (Hawkins and Rovira Kaltwasser 2017; Mudde 2017), discuss the complex relationship between populism and politics, and identify some of the main causes of the ongoing 'populist Zeitgeist'. My main arguments are: (1) while populism is related to (real and perceived) 'crises', crises are often catalysts rather than prime causes; (2) populism is essentially an illiberal democratic response to undemocratic liberalism; and (3) populism can only be overcome by more rather than less liberal democracy.

\section{Populism: a definition}

In my 2004 article I presented a new definition of populism that has since been used by a growing group of scholars and non-scholars - although it is important to note that there are also many who reject it (e.g. Aslanidis 2016; Freeden 2017). There is little doubt, however, that the ideational approach, in which populism is seen as a set of ideas centred on the notion that 'the people' are opposed to 'the elite', has reached a status that is as close to a consensus as academic approaches get. ${ }^{1}$ One of the few popular alternative approaches is the Laclauan approach (Laclau 2005; see also Borriello and Jäger 2020), which is often referred to as 'formal-discursive' (e.g. Stavrakakis et al. 2018), even if the differences between 'ideational' and 'Laclauan' scholars are often much smaller in empirical studies than the literature makes them out to be. ${ }^{2}$

While the ideational approach defines populism as a set of ideas, I specifically define it as a thin-centred ideology that considers society to be ultimately separated into two homogeneous and antagonistic groups: the pure people and the corrupt elite, which argues that politics should be an expression of the volonté générale (general will) of the people (Mudde 2004: 543). Let me briefly discuss a few specific aspects of my definition.

First of all, I call it a 'thin-centred' ideology, rather than an ideology per se, because populism alone does not tell us that much about what type of world populists want, like 'thick-centred' ideologies such as liberalism and socialism do. ${ }^{3}$ At the same time, I consider it a type of ideology, however limited, rather than just a 'discourse' or 'style', because it is not just an instrument for coming 
to power. It actually also informs policies when populists come to power or when they are empowered, as we can see from Hungary to Venezuela (e.g. Garcia-Guadilla and Mallen 2019; Mudde 2021; Palonen 2018).

Second, the basis of populism, in my understanding, is monism and moralism (see, in more detail, Mudde 2017). Populism is a monist ideology in that it sees 'the people' as one, with each individual member of 'the people' sharing exactly the same key interests and values. Populists do not believe in pluralism - that is, the view that society exists of different groups with diverse legitimate interests and where politics should find some type of consensus among (most of) these groups. For populists, there are only two groups, and only one is legitimate, because the elite are corrupt and therefore do not deserve the rights and protections of a legitimate opposition. This is not to say that populists do not distinguish between different groups on the basis of criteria such as class, ethnicity or religion, but rather that they argue that these citeria are secondary. Moreover, many populists argue that only one of these class, ethnic or religious groups is part of 'the people' for instance, in the discourse of many of the original American populists, 'the people' were white Christian farmers.

In addition to monism, moralism is central to my understanding of populism. For populists the distinction between the people and the elite is a moral one; it is about being morally pure versus morally corrupt. In other words, it is not about whether you have power or whether you have money. It is also not a class distinction. This explains why so many populist leaders are actually very wealthy, and some have been in power (e.g. Thaksin Shinawatra in Thailand) or close to power (e.g. Silvio Berlusconi in Italy) - in other words, most populists are insideroutsiders rather than true outsiders (see Mudde and Rovira Kaltwasser 2017). Wealth and power in themselves do not make one part of 'the elite'. What makes you part of the elite is having the wrong values, which today is often captured by terms such as 'cosmopolitanism', particularly among right-wing populists.

Third, monism and moralism are at the heart of the complex and controversial issue of the relationship between populism and democracy. Based upon my definition, populism is not necessarily bad for democracy, but it depends on the form (of democracy rather than of populism). In short, populism is pro-democracy but anti-liberal democracy. Very simply stated, if you see democracy in the Schumpeterian interpretation, ${ }^{4}$ it is about popular sovereignty and majority rule, which means that in a democratic system the people elect their leaders through a majority and that is it. Of course, what we generally talk about when we use the term democracy is much more than that, but technically that is liberal democracy, which combines popular sovereignty and majority rule with the protection of minority rights, rule of law, and separation of powers (e.g. Diamond 2003; Mouffe 2000). It is with those liberal protections that populism has a problem and the key reasons are their monism and moralism. When you believe that the people are homogeneous and that the only other group is the elite, which is corrupt, then there are no legitimate minority rights, because there is no legitimate minority. And if politics should be 'the general will of the people' then nothing can stand above that, not even a Supreme Court.

Fourth, populism is in itself neither left nor right, but most populist actors are. Whether populist parties or politicians are left or right depends not on their 
populism but on their host ideology, often a 'thick-centred' one. Almost all successful populists combine populism with a host ideology (see Mudde and Rovira Kaltwasser 2017). Populist radical right parties such as the Alternative for Germany (AfD) or the Indian People's Party (BJP) combine it with nativism, while left populist parties such as the Greek Coalition of the Radical Left (SYRIZA) or the South African Economic Freedom Fighters (EFF) combine it with some form of socialism.

Fifth, and final, populism is usually secondary to the host ideology. One of the few exceptions is the Italian Five Star Movement (M5S), whose 'eclectic populism' does not seem to have a stable host ideology (Mosca and Tronconi 2019). Almost all other populist parties are something else first and populist second. The Austrian Freedom Party (FPÖ) and Fidesz in Hungary are nativist first and populist second. Similarly, the Spanish Podemos and the United Socialist Party of Venezuela (PSUV) are socialist first, at least in name, and populist second. So, while this might be frustrating, it is very important to remember that populism can tell us only part of the story about 'the rise of populism'. When we want to understand the rise of the populist radical right or of left populist parties, populism is one part of the puzzle, and often only a minor part at that.

\section{The political paradox of populism}

That being said, there is something interesting to the rise of populism. If we think of the early 20th century, then most nativist and socialist movements were not populist. They were almost all elitist in some manner - that is, either extremist (i.e. anti-democratic) or paternalistic. Think about the various fascist movements and regimes, which abhorred democracy as rule of the 'mediocre' or 'weak', or the Marxism-Leninist parties and regimes, which believed that the Communist Party was the vanguard of the working class and supported a 'dictatorship of the proletariat'. Today, the main opposition to mainstream, liberal democratic politics is populist and I think that is something that we should think about much more.

For one of my courses, I was reading the great Seymour Martin Lipset, which really should be read by pretty much everyone and not just his classic Political Man (1960). Notably, in 1955, Lipset published an article on the radical right in America in the British Journal of Sociology that still offers the best explanation of the Trump phenomenon more than half a century later (Lipset 1955). But in another ground-breaking piece, 'Some Social Requisites of Democracy', he wrote that 'the characteristic pattern of stable western democracies in the mid-20th century is that of a "post-politics" phase - there is a little difference between the democratic left and right' (Lipset 1959: 100). I see the rise of populism very much in this context of what Lipset called 'post-politics', or what Arend Lijphart (1977) called 'depolarization' two decades later.

In what I see as the political paradox of populism, I am very much inspired by two of the smartest scholars who have written about populism. The first is Margaret Canovan, who sadly passed away in 2018 , but who has been massively influential to me, and the broader field, and is in many ways the real intellectual doyenne of contemporary populism studies (notably Canovan 1999). The second is Chantal Mouffe, who has a different interpretation of populism from mine, but whose analysis of liberal democracy has really been spot-on (notably Mouffe 2000). To be 
clear, I do not claim that Canovan or Mouffe see or saw the same paradox, but I would not have been able to see it myself without the foundational work of these two exceptional scholars.

The political paradox of populism is that populism is both at once anti-political and über-political. It is anti-political in the sense that it denies legitimate opposition - given that politics is about distribution of power and finding a kind of compromise or solution to different positions. As Jan Werner Müller (2016: 3) has summarized so cogently, 'they and they alone represent the people'. For populists there is no politics because (all) 'the people' are one. There is no reason to have deliberation or compromise, because if I am one of the people, then, what I think is good, all other members of 'the people' will think it is good too, as we all share the same core interests and values. At the same time, populism is über-political in that it considers everything subject to the will of the people. After all, politics should be an expression of 'the general will of the people' and nothing stands above that. In practice, it is the (re)politicization of politics that is at the heart of the populist claim.

As I will argue below, in essence, contemporary populism is an illiberal democratic response to undemocratic liberalism. It is a response to the depoliticization of politics, which has characterized (European) politics for at least four decades now. Where most mainstream politicians have increasingly been saying, 'we cannot decide that' or 'There Is No Alternative' (TINA), populists have responded by stating that everything is political. If the majority wants something, they have a democratic right to it. However, it is illiberal democratic, because, as argued above, it fundamentally rejects any type of limitation on the power of the majority. In a sense, it is a form of majoritarian extremism.

Before I discuss the key structural causes of the current populist Zeitgeist, let me sketch a short historical background of populism in Europe.

\section{A short history of populism in Europe}

Populism emerged in Europe in the mid-19th century with the Narodniki in Tsarist Russia, a small urban intellectual movement that left the city for the country to tell the peasants, 'You are the real people, you should have the power'. To their surprise, the peasants responded by saying, 'I don't really believe you and I need to work because otherwise I will die of hunger'. So, the populists decided to kill the tsar instead, which led to brutal repression and the (literal) death of the Narodniki and that was pretty much the story (Wortman 1967). The Narodniki had some influence in parts of Eastern Europe in the early 20th century (see Held 1996), but overall populism remained largely dormant within Europe until the 1980s.

There have been some local populist episodes in the early post-war period, such as the Poujadists in France, anti-tax parties in Denmark and Norway, and the Panhellenic Socialist Movement (PASOK) in Greece, but populism only gained broader relevance within (Western) Europe in the late 1980s, and more specifically the mid-1990s, with the rise of parties such as the French National Front (Betz 1994). The FN (now RN) was pretty much the prototype of what I have called the 'populist radical right' party (Mudde 2007). While now largely forgotten, parties like the FN and FPÖ already got some $15 \%$ of the national vote in the mid-1990s. 
In fact, the FPÖ received its record score not in 2017 but in 1999, when it gained $26.7 \%$ of the national vote.

The Great Recession boosted populism of both the left and the right, although not as much as is often assumed (see below). It gave a particular boost on the left, where broad anti-austerity protests led to the creation of Podemos in Spain and elevated SYRIZA from a marginal to a major party in Greece. While it also benefited some populist radical right parties, the overall effect of the Great Recession upon the populist radical right was fairly small (Mudde 2016). Roughly as many populist radical right parties experienced an increase as a decrease in their electoral support.

As illustrated in Figure 1, populist parties were fairly marginal in Europe until the 1980s and only started to increase their support in the 1990s. Since then, they have been trending upwards, quite rapidly in the 2010s, now averaging roughly $25 \%$ of the vote in national parliamentary elections within the European Union (plus UK). ${ }^{5}$ While this is significant, it is still just a fraction of the 'general will', which makes the massive literature on populism in general, and populist parties in particular, disproportionate at best, and excessive at worst.

But while support for populist parties is now almost Europe-wide, it is still very uneven across the continent. Table 1 provides an overview of the electoral support for populist parties in national elections in all EU countries (plus the UK). The first column contains the name of the country, the second the name of the biggest successful populist party in the country, the third that party's result in the last national election (before 2021), the fourth the total support for all populist parties in that country, the fifth the change in total populist support between the last and the preceding national elections, and the sixth the change in total support between the first post-crisis and the last pre-crisis national elections. ${ }^{6}$

Let's first look at the averages and trends. On average, the biggest populist party gains $17.4 \%$ of the votes, while the average total vote for populist parties is $25.5 \%$. In other words, on average, one in four EU citizens votes for a populist party in national elections - incidentally, the average support is not much higher in European elections. The trend is up, with populist parties winning, on average, $3.8 \%$ of the vote more in the last national election than in the one preceding it. However, there are massive differences within the EU. For instance, the biggest populist party won almost half of the vote in the last national election (Fidesz with 47.9\%), although they were hardly 'free and fair' (ODHIR 2018), while the smallest won less than 1\% (MPM with $0.4 \%$ ). Similarly, the total populist vote ranges from more than two-thirds (Hungary with 71.2\%) to less than 1\% (Malta with $0.4 \%)$.

Moreover, the averages are pushed up by a relatively small number of countries, as only one-third of countries ( 9 of the 28 ) have a total populist vote that is above the average of $25.5 \%$. In four countries the (vast) majority of the population votes for a populist party (Hungary, Italy, Slovakia and Slovenia), even if they are often divided over very different varieties of populism in each country (from radical left to radical right). And in only six countries the total populist vote is still in single digits. In the past five years, the total populist vote went up in 20 of the 28 countries, more than $70 \%$, but in only 10 substantially (i.e. by more than $5 \%)^{7}$ 


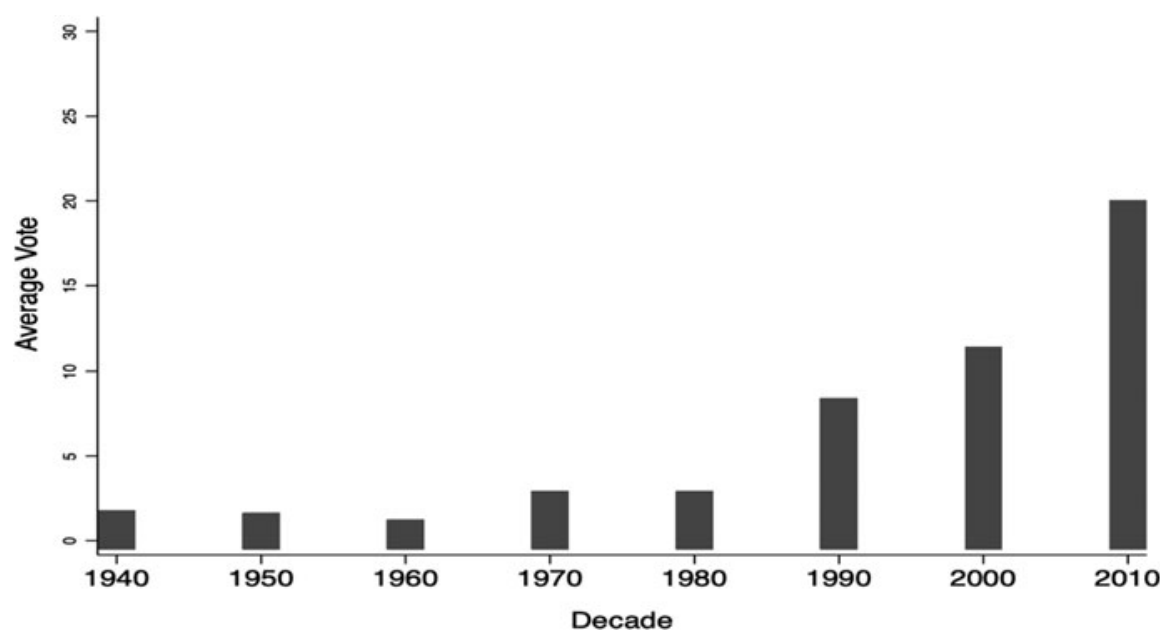

Figure 1. Average Electoral Support for European Populist Parties by Decade

Almost all theories of populism argue that populists thrive during 'crises', real or perceived (Moffitt 2016), even though the concept of 'crisis' remains one of the least clearly defined and theorized in the political science literature. It is therefore not surprising that the Great Recession was broadly seen to have been a big boon for populism. But, as so often, the picture was much more nuanced than received wisdom would have it (for an excellent study, see Kriesi and Pappas 2015). On average, populist parties gained $4.7 \%$ during the Great Recession, which is substantial, but not that striking. Only in eight countries did the total populist vote increase significantly - that is, by more than $10 \%$. Interestingly, the average in the 16 Eurozone countries (of that time) is only $0.1 \%$ higher. Perhaps most surprising is the fact that three of the five countries that received EU bailouts saw no change in the populist vote. This is not to say there is no effect from economic crises on support for populist parties, but rather that it might be delayed - as Béla Greskovits (1998) already argued a decade before the Great Recession, based on the Latin American experience of the late 20th century. This delayed populist surge has been most striking in Spain (with first Podemos and then VOX) and seems to have started more recently in Portugal too (with Chega).

So, if 'crises' are the catalysts rather than the causes of the rise of populism, what does explain the relatively recent rise of support for populist parties in Europe?

\section{Structural causes for the populist Zeitgeist}

Populism feeds off the inherent tensions of liberal democracy, most notably between majority rule and minority rights (Abts and Rummens 2007; Mouffe 2000). While it profits from (real or perceived) economic and political crises, like the Great Recession, its relatively recent rise has more structural causes. Brought back to the core, the current populist Zeitgeist is a consequence of a structural transformation that has (at least) three key aspects: (1) the rise of undemocratic 
Table 1. Support for Populist Parties in EU Member States (+UK) in Last Parliamentary Elections ${ }^{a}$

\begin{tabular}{|c|c|c|c|c|c|}
\hline Country & Biggest populist party & $\begin{array}{c}\% \\
\text { party }\end{array}$ & $\begin{array}{l}\% \\
\text { total }\end{array}$ & $\begin{array}{c}\% \text { total } \\
\text { change } \\
\text { last }\end{array}$ & $\begin{array}{c}\% \text { total } \\
\text { change } \\
\text { crisis }\end{array}$ \\
\hline Austria & Austrian Freedom Party (FPÖ) & 16.2 & 16.2 & -9.8 & +11.8 \\
\hline Belgium & Flemish Interest (VB) & 12.0 & 13.1 & +7.5 & -6.0 \\
\hline Bulgaria & $\begin{array}{l}\text { Citizens for European } \\
\text { Development of Bulgaria (GERB) }\end{array}$ & 32.7 & 41.7 & -8.7 & +17.1 \\
\hline Croatiab $^{\text {b }}$ & $\begin{array}{l}\text { Bridge of Independent Lists } \\
\text { (MOST) }\end{array}$ & 7.4 & 7.8 & -2.5 & -3.5 \\
\hline Cyprus & Citizens' Alliance (SYM/SYPOL) & 6.0 & 6.0 & +6.0 & 0.0 \\
\hline Czech Republic & $\begin{array}{l}\text { Action of Dissatisfied Citizens } \\
\text { (ANO 2011) }\end{array}$ & 29.6 & 42.0 & +14.0 & +11.7 \\
\hline Denmark & Danish People's Party (DF) & 8.7 & 11.1 & -10.0 & -1.6 \\
\hline Estonia & $\begin{array}{l}\text { Estonian Conservative People's } \\
\text { Party (EKRE) }\end{array}$ & 17.8 & 17.8 & +9.7 & 0.0 \\
\hline Finland & Finns Party (PS) & 17.5 & 18.5 & -0.7 & +15.0 \\
\hline France & National Front/Rally (FN/RN) & 13.2 & 24.2 & +3.7 & +16.2 \\
\hline Germany & Alternative for Germany (AfD) & 12.6 & 21.8 & +11.7 & +3.1 \\
\hline Greece & $\begin{array}{l}\text { Coalition of the Radical Left } \\
\text { (SYRIZA) }\end{array}$ & 31.5 & 38.7 & -0.5 & +21.5 \\
\hline Hungary & $\begin{array}{l}\text { Fidesz-Hungarian Civic } \\
\text { Movement (Fidesz) }\end{array}$ & 47.9 & 71.2 & +6.2 & +25.1 \\
\hline Ireland & Sinn Féin (SF) & 24.5 & 24.5 & +10.7 & +3.0 \\
\hline Italy & Five Star Movement (M5S) & 32.7 & 68.4 & +15.2 & +26.3 \\
\hline Latvia & Who Owns the State? (KPV LV) & 14.3 & 14.3 & +14.3 & 0.0 \\
\hline Lithuania & Labour Party (DP) & 9.8 & 15.4 & +4.7 & +4.7 \\
\hline Luxembourg & $\begin{array}{l}\text { Alternative Democratic Reform } \\
\text { Party (ADR) }\end{array}$ & 8.3 & 8.3 & +1.7 & -3.4 \\
\hline Malta & $\begin{array}{l}\text { Maltese Patriots Movement } \\
\text { (MPM) }\end{array}$ & 0.4 & 0.4 & +0.4 & 0.0 \\
\hline Netherlands & Party for Freedom (PVV) & 13.1 & 24.0 & +4.2 & -2.8 \\
\hline Poland & Law and Justice (PiS) & 43.6 & 43.6 & -2.8 & -3.8 \\
\hline Portugal & Enough! $(\mathrm{CH})$ & 1.3 & 1.3 & +1.3 & 0.0 \\
\hline Romania & Greater Romania Party (PRM) & 0.6 & 0.6 & -0.4 & +1.9 \\
\hline Slovakia & $\begin{array}{l}\text { Ordinary People and } \\
\text { Independent Personalities } \\
\text { (OL'ANO) }\end{array}$ & 25.0 & 54.7 & +0.1 & -1.0 \\
\hline Slovenia & $\begin{array}{l}\text { Slovenian Democratic Party } \\
\text { (SDS) }\end{array}$ & 24.9 & 51.6 & +22.7 & -7.4 \\
\hline Spain & VOX & 15.1 & 27.9 & +3.3 & 0.0 \\
\hline
\end{tabular}


Table 1. (Continued.)

\begin{tabular}{llcccc}
\hline Country & Biggest populist party & $\begin{array}{c}\% \\
\text { party }\end{array}$ & $\begin{array}{c}\% \text { total } \\
\text { total }\end{array}$ & $\begin{array}{c}\% \text { total } \\
\text { change } \\
\text { last } \\
\text { crisis }\end{array}$ \\
\hline Sweden & Sweden Democrats (SD) & 17.5 & 17.5 & +4.6 & +2.8 \\
UK & Brexit Party & 2.0 & 3.2 & +0.7 & 0.0 \\
Average & & 17.4 & $\mathbf{2 5 . 5}$ & +3.8 & +4.7 \\
\hline
\end{tabular}

Notes: ${ }^{a}$ I have followed the Popu-List for the classification of populist parties (Rooduijn et al. 2019). The last year to be included for national elections data is 2020 .

${ }^{\mathrm{b}}$ The scores for Croatia are particularly difficult to calculate, as most populist parties are small and part of larger, non-populist, coalitions.

liberalism; (2) a change in the relationship between the rulers and the ruled; and (3) the democratization of the media. While theoretically and empirically separate, these aspects are interconnected, thereby strengthening their collective effect.

The rise of undemocratic liberalism is debated under many different terms, including 'neoliberal globalization', 'post-democracy' and 'technocracy' (e.g. Crouch 2000; Mair 2013; Radaelli 2013). While many of these terms, and linked debates, focus almost exclusively on the economic dimension, I believe that the process of undemocratic liberalism goes well beyond neoliberal economics. While it is true that depoliticization had a particularly strong effect on the economic sector, through privatization and deregulation, many non-economic aspects were also 'liberalized'. Abortion and the death penalty are good examples of controversial issues that have become legalized in most European countries. Over the past decades, a lot of economic and political issues have become legal issues, which means they have been taken out of the political, most notably electoral, arena.

Formally, this was done democratically, but often only in the narrowest sense. While the politicians who implemented these policies were elected democratically - in free and fair elections - many of these decisions were taken largely without a public debate. As most political parties did not campaign on them, and sometimes did not even mention the policies in their election programmes, the decisions were made outside of popular control. This meant that most people had no real voice in the decision, as either the issue was not on the political agenda or most (major) parties held almost identical positions. Unsurprising, then, that many people are not even aware of some of these decisions.

Probably the best example of a liberal policy that was supported by all major mainstream parties, but kept from the political agenda for decades, is immigration. While immigration pre-dates the 'neoliberal era', it only became politicized in most European countries in the 1990s, with the electoral breakthrough of populist radical right parties. For decades, immigration policies, from 'guest workers' to East European 'refugees' to family reunion, were made outside of the electoral arena. Most immigration politics was democratic in process but undemocratic in spirit. They went against the spirit of democracy, in which the population debates policies and only then do the politicians make decisions on them. 
The process of European integration is another good example of undemocratic liberalism (see Parsons and Weber 2011). For decades European policies were made on the assumption that there was a so-called 'permissive consensus' within the European populations (Hooghe and Marks 2009) which 'legitimized' the pro-integration policies of the political elites - there might have been, but we will never know for sure, because public opinion polling on the topic remained fairly limited until the 1990s. The idea is that the European peoples did not know much about the process of European integration, but overall supported the content and direction of the process. Given the broad range of Euroscepticism that has become visible since European integration has become (reluctantly) politicized, again mostly by populist parties (de Vries 2018; Taggart 2004), it is highly likely that some key decisions would not have had majority support among the European peoples.

The most striking recent example is the Banking Union decision, a reaction to the chaotic and controversial EU fiscal responses to the Great Recession, which, simply stated, transfers the responsibility for banking policy from the national to the European level (see Baglioni 2016). Although this decision has been called 'one of the most significant developments in European integration since the agreement on Economic and Monetary Union in the Maastricht Treaty' (Howarth and Quaglia 2014: 125), it was discussed and decided almost exclusively outside of the democratic - that is, electoral - realm. Moreover, some of the key decisions about the specific mechanisms (the Single Supervision Mechanism (SSM) and the Single Resolutions Mechanism (SRM)) were only approved months before the 2014 European elections. So, while the decision was democratic in a purely procedural interpretation, it was not in a more substantial one. If the European elites had really wanted to have a popular mandate for their decision, they should have made the Banking Union a key issue in the election campaign. What better source of democratic legitimacy could there be?

Even after the 'Integration Consensus' of European integration, neoliberal economics and multi-ethnic societies was challenged by political newcomers, almost exclusively populist parties, most mainstream politicians responded with TINA politics. From the centre left to the centre right, fundamentally political decisions were depoliticized by the essentially anti-political argument that 'there is no alternative'. For instance, at the 2005 Labour Conference, British Prime Minister Tony Blair said, 'I hear people say we have to stop and debate globalisation. You might as well debate whether autumn should follow summer' (Blair 2005). Similarly, eight years later, and under pressure to defend his harsh austerity policies, his Tory 'successor' David Cameron said, 'There is no alternative that will secure our country's future' (Parker 2013).

In his posthumous masterpiece Ruling the Void, Peter Mair (2013) has explained this 'hollowing of western democracy' by the increased preference of 'responsible politics' over 'responsive politics' among mainstream governments and political parties. Responsive politics mean that governments and parties do what their voters want. Responsible politics mean that they do what they believe is 'responsible', which in the neoliberal era has become primarily defined by neoliberal economic theory and the whims of the international markets. In many cases, the consequence of 'responsible politics' is depoliticization. Policies are taken out of the political 
(electoral) arena through privatization, through politically independent 'expert' committees and institutions (like most central banks), or by killing the political debate by saying that 'there is no alternative' (see, among many others, Mouffe 2000; Streeck 2016).

Undoubtedly related to this process, we are now living in a period of nostalgia. Almost all major political camps are nostalgic for some previous era: the populist radical right for the 1950s, the (populist) 'radical' left for the 1960s, and the centre left and centre right for the 1980s and 1990s. ${ }^{8}$ What we often forget, however, is that for most of the 20th century, at least in Europe, politics was quite elitist, or better paternalistic, with most of the (cultural, economic and political) elites distrusting the people. It was distrust of 'the people' that explains why democracy was introduced so gradually and slowly in Western Europe (e.g. de Dijn 2020). Even after universal suffrage was finally introduced, in the early 20th century, many elites saw their fears confirmed in the Weimar Republic, as received wisdom has it that 'the people' abolished democracy by voting the Nazis into power. No matter that 'only' one-third of the people had voted for the Nazis and that Adolf Hitler could only come to power because of collaboration by conservative elites (Capoccia 2005; Ziblatt 2017). As elitism softened into paternalism in the post-war period, elites remained convinced that they knew better than the people what was good for them, while most people seemed fine with that, having been socialized into the same paternalistic spirit by churches, schools and trade unions.

This situation is gradually coming to an end as a consequence of the 'silent revolution' (Inglehart 1977). As post-war generations increasingly grew up under conditions of economic affluence and physical security, they developed 'post-materialist' priorities. A less mentioned aspect of this development is what Ronald Inglehart has called 'cognitive mobilization', which means that new generations have become better educated and have developed more political efficacy or self-consciousness. As a consequence, post-materialist generations are less deferential to power and feel that they can make political decisions as well, or even better, than the political elites.

At the same time, we have seen the rise of a 'political class', an increasingly closed and homogeneous group of professional politicians (e.g. Aberbach et al. 1981; von Beyme 1996; Borchert and Zeiss 2003; Cotta and Best 2007). While it is important to acknowledge that politicians have become more diverse in some respects, most notably in terms of gender but also, albeit to an even lesser extent, sexuality and ethnicity (e.g. Dancygier 2017; Kittilson 2006), professional politicians have become more and more homogeneous in terms of class as well as level of education (Gaxie and Godmer 2007). ${ }^{9}$ Irrespective of party ideology, the average 'career politician' today comes from an (upper) middle-class background, is a university graduate and comes from a 'brokerage occupation' like journalism or law (Norris 1999). This is even the case for Christian democratic and social democratic parties, which used to have much broader representation, most notably by farmers and workers, respectively. Today, most workers tend to be found in the representation of communist parties and, ironically, populist radical right parties. ${ }^{10}$

These conflicting processes have reshaped the most fundamental relationship in a democracy, that between the rulers (elites) and the ruled (masses/people). While the masses have become much more democratized, for the first time feeling that 
they are (or should be) equal participants in the democratic process, the elites have become more homogeneous and segregated, in terms of their sociodemographic characteristics. Moreover, in the neoliberal era, political elites have become more elitist in a 'technocratic' sense, believing that more and more things should be decided by 'experts', most notably (neoliberal) economic experts and within the EU (see Radaelli 2013).

Finally, politics has changed fundamentally because of the democratization of the media. For much of the 20th century, European media were either controlled by the state or by major political actors such as churches, political parties and trade unions. Radio and later television were almost exclusively publicly owned and operated, and while the level of political influence differed significantly (not just between the East and West, but also within the West), ultimate control rested with the mainstream parties. The rise of private media changed not just the media landscape but also the media logic (e.g. Mazzoleni 2008).

Private television emerged in much of Europe in the 1980s and had a massive effect on what people could and did watch (see Michalis 2013). During the same time, many of the newspapers were also privatized, losing financial backing from mainstream political actors, which changed their media logic. Traditional media outlets no longer simply had to report the news, within the limits set by their mainstream backers and controllers, but they had to make money too. As traditional media started to 'chase eyeballs', they increasingly copied the content and style of the private media, which shows a strong overlap with that of (radical right) populists (Ellinas 2010).

On the one hand, this process had a democratizing effect on the media in terms of control, as the old elites, which could largely decide what was or was not addressed in the media, lost much of their gatekeeping power (Bro and Wallberg 2014). On the other hand, it created new gatekeepers, mostly economic elites, and led to a different narrowing of the issues addressed. After all, we all know what sells: scandals and controversy (Tumber 1993). And populists offer that in multitude. So, without traditional gatekeepers and with a new media logic, populists became a rare political milk cow for the highly competitive and chronically underfunded private media. This allowed the more media-savvy populists to help set the political agenda, further benefiting them electorally (e.g. Mazzoleni et al. 2003; Walgrave and De Swert 2004; Wettstein et al. 2018).

The agenda-setting and gatekeeping functions of the traditional elites are further eroded by the rising importance of social media. This is what I call the Bieber effect. Justin Bieber was a massive star on YouTube first. And anything that is big on social media, like Twitter and YouTube, is going to find its way into the traditional media. Populism has an 'elective affinity' with social media, among others in their shared 'rebellious narrative' (Gerbaudo 2018), which might explain why many populist actors and arguments are disproportionately visible on social media (e.g. Alonso-Muñoz and Casero-Ripollés 2018; Engesser et al. 2017), often seeming much more popular than they actually are in the real world. Given that journalists, who are disproportionately active on social media like Twitter, are heavily influenced in their choice and framing of their news stories by the Twitter accounts they follow (see Wihbey et al. 2017), they (unwittingly) help amplify the messages and relevance of populists. 
Still, it is important not to overstate the importance of social media. So far, most research shows that social media intensifies opinions rather than changes them. Moreover, regular social media use is still limited to small parts of the broader population. While a majority of Europeans are on Facebook, except in Germany, there are important generational variations (de Best 2018). Moreover, participation on other social media platforms is much lower. For instance, in October 2020, the European country with the largest Twitter population was the UK with 16.65 million users, which is one-quarter of the population. But in Germany, 5.45 million people were on Twitter, which is just $6.5 \%$ of the population (Statista 2021). In addition, US-based research shows that 'most users rarely tweet, but the most prolific $10 \%$ create $80 \%$ of tweets from adult U.S. users' (Wojcik and Hughes 2019).

Hence, without adoption by traditional media, the political effects of social media remain fairly limited. A good example is Donald Trump's victory in the 2016 US presidential elections, which is often explained by his massive Twitter presence. But social media did not win Trump the election. First of all, Trump only had such a massive Twitter presence because of the fame he had amassed through traditional media, most notably his TV show The Apprentice, which aired on one of the three major networks in the US. And it was traditional media, from CNN to the New York Times, which gave Trump excessive coverage estimated to have been worth almost US\$ 6 billion (Sultan 2017). While it is undoubtedly true that his Twitter presence helped increase his disproportionate coverage, it was gatekeepers in the traditional media that decided to grant him access and bring his message from his few million Twitter followers to the hundreds of millions of traditional media consumers.

\section{What can we do?}

The question that I always get asked after a lecture on populism is, what can we do? Unfortunately, I don't know if I have the right answer to that question. But what is very important to note is that populism is much more the symptom than the cause of the current problems. It is a symptom of a malfunctioning liberal democracy. Now, once it comes to power, it creates massive problems. Hungary shows that, but even Hungary has bigger problems than just Fidesz. It wasn't that Hungary was doing fantastically well before Viktor Orbán returned to power. Orbán won because Socialist Prime Minister Ferenc Gyurcsany was caught on tape saying that they had lied about everything to win the elections. So, clearly, Hungarian democracy was not doing particularly well.

For me, the real question is not how we defeat populism, but how can we strengthen liberal democracy? This is not the same question. If you merely defeat populism, liberal democracy is still in trouble. However, if you strengthen liberal democracy, by definition populism also gets weaker. But how do you strengthen liberal democracy? Let's first discuss two popular responses that do more harm than good, anti-populism and technocracy (which sometimes are combined).

Anti-populism claims that 'we', the liberal democrats, are the pure ones and 'they', the populists, are the corrupt ones. It is the mirror image of populism, which means that it is also monist and moralist, and therefore loathes compromise. Anti-populism has been a popular response against populist governments like the 
SYRIZA government in Greece (Stavrakakis et al. 2018). And it has become even more widespread within the disposed political mainstream after the populist double whammy of Brexit and Trump in 2016. A particular painful example of antipopulism was Hillary Clinton's infamous 'deplorables' speech, in which she said, 'You know, to just be grossly generalistic, you could put half of Trump's supporters into what I call the basket of deplorables. Right?' (Reilly 2016). While I do not wish to claim that anti-populism is as detrimental to liberal democracy as populism this remains an empirical question - it is important to note that it has some of the same anti-liberal democratic assumptions about society and politics.

Another response to populism is technocracy - rule by experts ('technocrats'). As argued before, technocratic arguments have become increasingly powerful in the neoliberal era, particularly within the EU (e.g. Mair 2013). While populism and technocracy are diametrically opposed in some ways, notably the valuation of 'the people', they share important positions, which are highly problematic for liberal democracy. In essence, both are anti-political, pretending to have the (one) answer to all problems. They also share a critique of 'the party model of representative democracy', which is foundational to European democracies (Caramani 2017). So, even if technocracy would be able to defeat populism, it will not save liberal democracy. But given that it is technocracy (i.e. undemocratic liberalism) that has created populism, as I argued above, it is probably not even able to defeat it.

What we need is more rather than less politics. While it might sound odd, populism can only be defeated by repoliticizing politics. Not through a populist debate, but through a liberal democratic debate. As Müller (2016) has so aptly stated, 'talking with populists is not the same as talking like populists'. This does not necessarily have to mean that we should create completely different policies. We probably do not have to go back on European integration or even neoliberal economics, which I am personally not a fan of, but perhaps a majority of the population is. What it means is that, when politicians argue that we should have more European integration, they explain why they believe that is the case. Sure, point out the problems with the alternatives, but mostly emphasize and explain the benefits of your own position.

It has become received wisdom that you cannot defeat populists with mainstream politics. Within the (centre) left, it has become popular to argue that right-wing populism can only be defeated by left-wing populism (e.g. Mouffe 2019). This is a remarkably defeatist position, particularly given that populists still attract only a minority of the population in most European countries. I do not believe that we need populism, leftist or centrist, to defeat right-wing populism. Nor do I believe that we cannot win the political debate with liberal democratic arguments. Politicians from Biden to Merkel show that, election after election. And I am convinced that if the Remain camp had based its campaign on emphasizing the positive aspects of EU membership, rather than on the (alleged) dangers of leaving the EU, the UK would still be in the EU today.

Paradoxically, the populist Zeitgeist is happening as people are overwhelmingly democratic and increasingly liberal (e.g. Kriesi 2020). In fact, Europeans are actually behaving now as democratic theory has always said democratic citizens should behave. They make their own decisions, rather than follow their husband, priest 
or union leader. Europeans are also much more liberal than they have ever been. Sure, Islamophobia is a massive problem. But, let's face it, if we had had a poll on Islamophobia in the 1950s, the results would have been the same, if not even worse. Yet, if you look at views on gender equality and homosexuality, Europeans today are (much) more liberal than previous generations (e.g. Wike et al. 2019; Wilson 2020). So, at least in that sense radical right-wing populism is actually representing more the past than the future.

The main challenge of contemporary European politics is not populism, it is the ideological vacuum at the heart of the political mainstream. Social democratic parties have lost their way with the Third Way, which reduced them to a lesser form of the centre right (e.g. Streeck 2016). But centre-right parties are experiencing a similar development at the moment, where they experience temporary success on the basis of someone else's ideology - that is, the populist radical right - while slowly but steadily losing their ideological and support base (Bale and Rovira Kaltwasser 2021). It is high time that liberal democrats started to tell a convincing ideological story again. That story should be Christian-democratic, social-democratic, green, liberal, conservative. We need many different stories, reflecting and acknowledging the many different groups and views our societies count. The different ideological stories should emphasize the differences between them, but they should also explicitly acknowledge that the other parties are opponents with different but legitimate views, and not enemies (Mouffe 2000). They should also emphasize that compromise is the essence of liberal democratic politics.

It is time to end the populist Zeitgeist. One of the most important steps to do this is to stop using the term 'the people' in a homogeneous way and claim that one party or politician knows what is good for 'the people' or represents 'the people'. We have to acknowledge that there is nothing that is good for all people, or at least for all the people in the same way. Not even environmental protection. Sure, it is great to implement policies so that we do not all die, but even these policies will be much more expensive or intrusive for some people than for others - a lesson that French President Emanuel Macron has learned the hard way with the populist Yellow Vests protests. Only by emphasizing and legitimizing the different groups, interests and values that exit in all societies can we rejuvenate liberal democracy. Time to return to a pluralist Zeitgeist.

\section{Epilogue: populism and COVID-19}

The last years have been dominated by COVID-19, which has also led to a frenzy of speculation on what the effects of the pandemic would be on populism. Unsurprisingly, most assessments were heavily influenced by Trump, or another specific national context, which led to regional and even global generalizations on an $\mathrm{N}$ of 1 . Several authors saw negative effects of the pandemic. Hans-Georg Betz (2021) declared populism to be one of 'Coronavirus-19s victims', while Valerio Alfonso Bruno and James Downes (2021) argued that 'populist radical right parties (PRR) have had their raison d'etre taken away from them and have been left powerless politically, in the face of the pandemic'. In sharp contrast, Paolo Gerbaudo (2020) argued that Europe is awaiting 'something much worse than the populist right of the 2010s: an extreme right using the whole arsenal of 
the red scare and rightwing authoritarianism to intimidate opponents and defend its interests from demands for meaningful economic redistribution'.

Several studies have shown that most of the received wisdom about populism and the pandemic has been wrong. In short, populists did not all deny or minimize the pandemic, populists in government were overall not more or less (in)competent than non-populist governments, and 'populism' was neither killed nor strengthened by COVID-19 (e.g. Meyer 2020; Wondreys and Mudde 2021). This should not have come as a surprise, as populist actors are highly diverse, ranging from the radical left to the radical right. Moreover, populist parties and politicians find themselves in very varied political positions: one-party governments, part of a broader coalition, and parliamentary or extra-parliamentary opposition. That said, it is true that more and more populist parties and politicians have become sceptical of preventative measures, from face masks to lockdowns, in the second wave.

In a more theoretical sense, as a thin-centred ideology, populism does not have a position on public health issues. It has been argued that populism is inherently opposed to 'experts', but that is a simplification. In practice, populists have regularly propagated and used experts (see Taggart 2000). What they oppose is a 'government by experts', in which experts are above 'the general will of the people' (Müller 2020). As a political issue, the pandemic can be put in the general framework of populism as an illiberal democratic response to undemocratic liberalism. Many European populists, particularly those in opposition, have presented themselves as the voice of 'the people' against the 'corrupt', 'incompetent' and 'undemocratic' COVID-19 policies of the political and public health elite (Wondreys and Mudde 2021).

Still, the pandemic does not seem to be a big winning issue for populists. Although populist parties tend to be the only major parties to criticize the other parties (government and opposition) for ignoring 'the people' and for pushing 'undemocratic' policies, the issue is not that easy to link to their core message. As economies are hard-hit, left populists struggle to get support for higher taxes and more redistribution, even if austerity policies are less popular today than during the Great Recession. And populist radical right parties have been robbed of their key nativist policy, the closing of borders, as almost all countries decided to do this early on, with support from most main parties. If anything, this shows, again, that populism is secondary to most populist parties, and mainly strengthens the host ideology, be it nativism on the right or socialism on the left.

Acknowledgements. I would like to thank the editors of Government and Opposition, Laura Cram and Erik Jones, for the original invitation to give the 2019 Government and Opposition/Leonard Schapiro Lecture, which was a true and unexpected honour. I also want to thank the two reviewers for their constructive criticism, Jan Jagers and Cristóbal Rovira Kaltwasser for their insights and support, without which I would never have been able to develop most of the ideas presented in this article, and Jakub Wondreys, for his invaluable research assistance. Finally, I want to thank the late Peter Mair, for believing in me, and for pushing me far beyond my comfort zone and natural inhibitions. I could not have wished for a better academic mentor. You and your work are sorely missed.

\section{Notes}

1 This is not the place to revisit the ever-growing debate on the definition of populism, which continues to dominate (too) much of the academic and public debate on the phenomenon. I have discussed this before 
(e.g. Mudde 2017) and there are various other publications that provide great overviews of the debate (e.g. Moffitt 2020; Rovira Kaltwasser et al. 2017b).

2 To be absolutely clear, I reject the notion that there is a 'Muddean camp' or even a 'Muddean frame' (Maiguashca 2019). Unlike Laclau, I did not create a new approach, but rather clarified, and perhaps helped popularize, the much older ideational approach, which can already be found in most foundational texts of the comparative study of populism (see, for example, Canovan 1981; Gellner and Ionescu 1970).

3 The distinction between 'thin-centred' and 'thick-centred' ideologies comes from Michael Freeden (1998), although I would like to note that Freeden himself does not see populism as a 'thin-centred ideology' (Freeden 2017; see also Aslanidis 2016).

4 The Austrian political economist Joseph Schumpeter famously defined democracy as a mere procedure: 'The democratic method is that institutional arrangement for arriving at political decisions which realizes the common good by making the people itself decide issues through the election of individuals who are to assemble in order to carry out its will' (Schumpeter 1956: 269).

5 The figure includes elections until 2017, but the overall score of populist parties has not changed significantly in the last few years.

6 While the exact start and end of the economic crisis of the Great Recession is difficult to pinpoint for each country, but in line with assessments by economists (Uhlig 2010), I have dated the crisis from early 2008 to mid-2009. Hence, the 'Change crisis' column reports the total percentage of populist support in the first national legislative election since 2010 minus that of the last elections before 2008 .

7 This increase was almost exclusively on the right, which is probably a consequence of the so-called 'refugee crisis', which has transformed European politics significantly (see Mudde 2019).

8 The importance of nostalgia to populism has often been (casually) noted in public debates, but has so far received little academic attention. A ground-breaking new study shows the importance of nostalgia for different forms of populism in Turkey (Elçi 2021).

9 While the professionalization and homogenization are Europe-wide trends, important national differences in elite recruitment remain (see, for instance, Hartmann 2006).

10 Unfortunately, there is not much comparative research on far-right MPs, let alone on their sociodemographic characteristics. One of the few comparative sources draws disproportionately from parties of the first two waves of the post-war far right (Linz et al. 2007), so I build here mainly on my own comparative observations as well as on some national studies (e.g. Wauters 2012).

\section{References}

Aberbach J, Putnam RD and Brockman B (1981) Bureaucrats and Politicians in Western Democracies. Cambridge, MA: Harvard University Press.

Abts K and Rummens S (2007) Populism Versus Democracy. Political Studies 55(2), 405-422. https:/doi. org/10.1111\%2Fj.1467-9248.2007.00657.x.

Alonso-Muñoz L and Casero-Ripollés A (2018) Communication of European Populist Leaders on Twitter: Agenda Setting and the 'More is Less' Effect. El Profesional de la Información 27(6), 1193-1202. https:// doi.org/10.3145/epi.2018.nov.03.

Aslanidis P (2016) Is Populism an Ideology? A Refutation and a New Perspective. Political Studies 64(1), 88-104. https://doi.org/10.1111\%2F1467-9248.12224.

Baglioni A (2016) The European Banking Union: A Critical Assessment. London: Palgrave Macmillan.

Bale T and Rovira Kaltwasser C (eds) (2021) Riding the Populist Wave: Europe's Mainstream Right in Crisis. Cambridge: Cambridge University Press.

Betz HG (1994) Radical Right-Wing Populism in Western Europe. Basingstoke: Macmillan.

Betz HG (2021) Coronavirus-19's Victims: Populism. In Bar-On T and Molas B (eds), Radical Right-Wing Responses to COVID-19. Stuttgart: Ibidem, forthcoming.

Blair T (2005) Tony Blair's Conference Speech. Guardian, 27 September. www.theguardian.com/uk/2005/ sep/27/labourconference.speeches.

Borchert J and Zeiss J (2003) The Political Class in Advanced Societies: A Comparative Handbook. Oxford: Oxford University Press.

Borriello A and Jäger A (2020) The Antinomies of Ernesto Laclau: A Reassessment. Journal of Political Ideologies, published early online, December. https://doi.org/10.1080/13569317.2020.1855775. 
Bro P and Wallberg F (2014) Gatekeeping in a Digital Era: Principles, Practices and Technological Platforms. Journalism Practice 9(1), 92-105. https://doi.org/10.1080/17512786.2014.928468.

Bruno VA and Downes JF (2021) COVID-19 and the (Temporary) Fall of the Populist Radical Right in European Politics? In Bar-On T and Molas B (eds), Radical Right-Wing Responses to COVID-19. Stuttgart: Ibidem, forthcoming.

Canovan M (1981) Populism. London: Harcourt Brace Jovanovich.

Canovan M (1999) Trust the People! Populism and the Two Faces of Populism. Political Studies 47(1), 2-16. https://doi.org/10.1111\%2F1467-9248.00184.

Capoccia G (2005) Defending Democracy: Reactions to Extremism in Interwar Europe. Baltimore: Johns Hopkins University Press.

Caramani D (2017) Will vs. Reason: The Populist and Technocratic Forms of Political Representation and Their Critique to Party Government. American Political Science Review 111(1), 54-67. https://doi.org/10. $1017 /$ S0003055416000538.

Cotta M and Best H (eds) (2007) Democratic Representation in Europe: Diversity, Change, and Convergence. Oxford: Oxford University Press.

Crouch C (2000) Post-Democracy. Cambridge: Polity.

Dancygier D (2017) Dilemmas of Inclusion: Muslims in European Politics. Princeton: Princeton University Press.

De Best R (2018) Half of Europe Uses Facebook, Statista, 30 November. www.statista.com/chart/16256/ facebook-users-in-europe.

De Dijn A (2020) Freedom: An Unruly History. Cambridge, MA: Harvard University Press.

De Vries C (2018) Euroscepticism and the Future of Europe. Oxford: Oxford University Press.

Diamond L (2003) Defining and Defending Democracy. In Dahl RA, Shapiro I and Cheibub JA (eds), The Democracy Sourcebook. Cambridge, MA: MIT Press, pp. 29-39.

Elçi E (2021) Politics of Nostalgia and Populism: Evidence from Turkey. British Journal of Political Science, published early online, January. https://doi.org/10.1017/S0007123420000666

Ellinas AA (2010) The Media and the Far Right in Western Europe: Playing the Nationalist Card. Cambridge: Cambridge University Press.

Engesser S, Ernst N, Esser F and Büchel F (2017) Populism and Social Media: How Politicians Spread a Fragmented Message. Information, Communication \& Technology 20(8), 1109-1125. https://doi.org/10. 1080/1369118X.2016.1207697.

Freeden M (1998) Is Nationalism a Distinct Ideology? Journal of Political Ideology 46(4), 748-765. https:// doi.org/10.1111/1467-9248.00165.

Freeden M (2017) After the Brexit Referendum: Revisiting Populism as an Ideology. Journal of Political Ideologies 22(1), 1-11. https://doi.org/10.1080/13569317.2016.1260813.

Garcia-Guadilla MP and Mallen A (2019) Polarization, Participatory Democracy, and Democratic Erosion in Venezuela's Twenty-First Century Socialism. Annals of the American Academy of Political and Social Science 681(1), 62-77. https://doi.org/10.1177\%2F0002716218817733.

Gaxie D and Godmer L (2007) Cultural Capital and Political Selection: Educational Backgrounds of Parliamentarians. In Cotta M and Best H (eds), Democratic Representation in Europe: Diversity, Change, and Convergence. Oxford: Oxford University Press, pp. 106-135.

Gellner E and Ionescu G (eds) (1970) Populism: Its Meanings and National Characteristics. London: Weidenfeld \& Nicolson.

Gerbaudo P (2018) Social Media and Populism: An Elective Affinity. Media, Culture \& Society 40(5), 745-753. https://doi.org/10.1177\%2F0163443718772192.

Gerbaudo P (2020) Coronavirus Embarrassed Trump and Bolsonaro. But the Global Right Will Fight Back, Guardian, 1 April. www.theguardian.com/commentisfree/2020/apr/01/populist-right-coronavirus.

Greskovits B (1998) The Political Economy of Protest and Patience: Easy European and Latin American Transformations Compared. Budapest: Central European University Press.

Hartmann M (2006) The Sociology of Elites. London: Routledge.

Hawkins KA and Rovira Kaltwasser C (2017) The Ideational Approach to Populism. Latin American Research Review 52(4), 513-528. http://doi.org/10.25222/larr.85.

Held J (ed.) (1996) Populism in Eastern Europe: Racism, Nationalism, and Society. New York: East European Monographs. 
Hooghe L and Marks G (2009) A Postfunctionalist Theory of European Integration: From Permissive Consensus to Constraining Dissensus. British Journal of Political Science 39(1), 1-23. https://doi.org/ 10.1017/S0007123408000409.

Howarth D and Quaglia L (2014) The Steep Road to European Banking Union: Constructing the Single Resolution Mechanism. Journal of Common Market Studies 52(Annual Review), 125-140. https://doi. org/10.1111/jcms.12178.

Inglehart R (1977) The Silent Revolution: Changing Values and Political Styles Among Western Publics. Princeton: Princeton University Press.

Jagers J (2006). De Stem van het Volk! Populism als concept getest bij Vlaamse politieke partijen. Unpublished $\mathrm{PhD}$. University of Antwerp.

Kittilson MC (2006) Challenging Parties, Changing Parliaments: Women and Elective Office in Contemporary Western Europe. Columbus, OH: Ohio State University Press.

Kriesi H (2020) Is There a Crisis of Democracy in Europe? Politische Vierteljahresschrift 61, 237-260. https://doi.org/10.1007/s11615-020-00231-9.

Kriesi H and Pappas T (eds) (2015) European Populism in the Shadow of the Great Recession. Colchester: ECPR Press.

Laclau E (1977) Politics and Ideology in Marxist Theory: Capitalism - Fascism - Populism. Atlantic Heights, NJ: Humanities Press.

Laclau E (2005) On Populist Reason. London: Verso.

Lijphart A (1977) Democracy in Plural Societies: A Comparative Exploration. New Haven, CT: Yale University Press.

Linz JJ, Mír MJ and Ortega M (2007) The Extreme Right. In Cotta M and Best H (eds), Democratic Representation in Europe: Diversity, Change, and Convergence. Oxford: Oxford University Press, pp. 316-352.

Lipset SM (1955) The Radical Right: A Problem for American Democracy, British Journal of Sociology 6(2), 176-209.

Lipset SM (1959) Some Social Requisites of Democracy: Economic Development and Political Legitimacy. American Political Science Review 53(1), 69-105. https://doi.org/10.2307/1951731.

Lipset SM (1960) Political Man: The Social Bases of Politics. New York: Anchor.

Maiguashca B (2019) Resisting the 'Populist Hype': A Feminist Critique of a Globalizing Concept. Review of International Studies 45(5), 768-785. https://doi.org/10.1017/S0260210519000299.

Mair P (2013) Ruling the Void: The Hollowing of Western Democracy. London: Verso.

Mazzoleni G (2008) Media Logic. In Donsbach W (ed.), The International Encyclopedia of Communication. Hoboken, NJ: Wiley.

Mazzoleni G, Stewart J and Horsfield B (eds) (2003) The Media and Neo-Populism: A Contemporary Comparative Analysis. Westport, CT: Praeger.

Meyer B (2020) Pandemic Populism: An Analysis of Populist Leaders' Responses to Covid-19. London: Tony Blair Institute for Global Change.

Michalis M (2013) Thirty Years of Private Television in Europe - Trends and Key Moments. In Donders K, Pauwels C and Loisen J (eds), Private Television in Western Europe. London: Palgrave Macmillan, pp. 37-55.

Moffitt B (2016) The Global Rise of Populism: Performance, Political Style, and Representation. Redwood City, CA: Stanford University Press.

Moffitt B (2020) Populism. Cambridge: Polity.

Mosca L and Tronconi F (2019) Beyond Left and Right: The Eclectic Populism of the Five Star Movement. West European Politics 42(6), 1258-1283. https://doi.org/10.1080/01402382.2019.1596691.

Mouffe C (2000) The Democratic Paradox. London: Verso.

Mouffe C (2019) For a Left Populism. London: Verso.

Mudde C (2004) The Populist Zeitgeist, Government and Opposition: An International Journal of Comparative Politics 39(4), 541-563. https://doi.org/10.1111/j.1477-7053.2004.00135.x.

Mudde C (2007) Populist Radical Right Parties in Europe. Cambridge: Cambridge University Press.

Mudde C (2016) On Extremism and Democracy in Europe. London: Routledge.

Mudde C (2017) An Ideational Approach. In Rovira Kaltwasser C, Taggart P, Ochoa Espejo P and Ostiguy

P (eds), The Oxford Handbook on Populism. Oxford: Oxford University Press, pp. 27-47.

Mudde C (2019) The 2019 EU Elections: Moving the Center. Journal of Democracy 30(4), 20-34. 
Mudde C (2021) Populism and Constitutionalism: Theory and Practice. In Holtug N and Uslaner E (eds), National Values and Social Cohesion. Colchester: ECPR Press, forthcoming.

Mudde C and Rovira Kaltwasser C (2017) Populism: A Very Short Introduction. Oxford: Oxford University Press.

Müller JW (2016) What Is Populism? Philadelphia: University of Pennsylvania Press.

Müller JW (2020) Why Do Rightwing Populist Leaders Oppose Experts. The Guardian, 26 March. www. theguardian.com/commentisfree/2020/mar/26/rightwing-populist-leaders-oppose-experts-not-elites.

Norris P (1999) Recruitment in the European Parliament. In Katz RS and Wessels B (eds), The European Parliament, the National Parliaments, and European Integration. Oxford: Oxford University Press, pp. 86-102.

ODIHR (2018) Hungary: Parliamentary Elections 8 April 2018. Warsaw: OSCE ODIHR.

Palonen E (2018) Performing the Nation: The Janus-Faced Populist Foundations of Illiberalism in Hungary. Journal of Contemporary European Studies 26(3), 308-321. https://oi.org/10.1080/14782804.2018. 1498776.

Parker G (2013) There Is No Alternative, Says Cameron. Financial Times, 7 March. www.ft.com/content/ 3a39ea0e-8723-11e2-bde6-00144feabdc0.

Parsons C and Weber T (2011) Cross-Cutting Cleavages and Party Strategy in the European Union. Comparative Political Studies 44(4), 383-411. https://doi.org/10.1177\%2F0010414010393474.

Radaelli CM (2013) Technocracy in the European Union. London: Routledge.

Reilly K (2016) Read Hillary Clinton's 'Basket of Deplorables' Remarks About Donald Trump Supporters. Time, 10 September. https://time.com/4486502/hillary-clinton-basket-of-deplorables-transcript.

Rooduijn M et al. (2019) The PopuList: An Overview of Populist, Far Right, Far Left and Eurosceptic Parties in Europe. www.popu-list.org.

Rovira Kaltwasser C, Taggart P, Ochoa Espejo P and Ostiguy P (2017a) Populism: An Overview of the Concept and the State of the Art. In Rovira Kaltwasser C, Taggart P, Ochoa Espejo P and Ostiguy P (eds), The Oxford Handbook on Populism. Oxford: Oxford University Press, pp. 1-24.

Rovira Kaltwasser C, Taggart P, Ochoa Espejo P and Ostiguy P (eds) (2017b) The Oxford Handbook on Populism. Oxford: Oxford University Press.

Schumpeter J (1956) Capitalism, Socialism and Democracy. New York: Harper and Row.

Statista (2021) Leading Countries Based on Number of Twitter Users as of January 2021. Statista. www. statista.com/statistics/242606/number-of-active-twitter-users-in-selected-countries.

Stavrakakis Y, Katsambekis G, Kioupkiolis A and Siomos T (2018) Populism, Anti-Populism and Crisis. Contemporary Political Theory 17(1), 4-27. https://doi.org/10.1057/s41296-017-0142-y.

Streeck W (2016) How Will Capitalism End? Essays on a Failing System. London: Verso.

Sultan NM (2017) Election 2016: Trump's Free Media Helped Keep Cost Down, But Fewer Donors Provided More of the Cash. OpenSecrets, 13 April. www.opensecrets.org/news/2017/04/election-2016trump-fewer-donors-provided-more-of-the-cash.

Taggart P (2000) Populism. Buckingham: Open University Press.

Taggart P (2004) Populism and Representative Politics in Contemporary Europe. Journal of Political Ideologies 9(3), 269-288. https://doi.org/10.1080/1356931042000263528.

Tumber H (1993) 'Selling Scandal': Business and the Media. Media, Culture \& Society 15(3), 345-361. https://doi.org/10.1177\%2F016344393015003002.

Uhlig H (2010) Euro Area Business Cycle Dating Committee: Determination of the 2009 Q2 Trough in Economic Activity. VoxEU.org, 4 October. voxeu.org/article/when-did-eurozone-recession-end.

von Beyme K (1996) The Concept of Political Class: A New Dimension of Research on Elites? West European Politics 19(1), 68-87. https://doi.org/10.1080/01402389608425121.

Walgrave S and De Swert K (2004) The Making of the (Issues of the) Vlaams Blok. Political Communication 21(4), 479-500. https://doi.org/10.1080/10584600490522743.

Wauters B (2012) Blue Collars Striking the Red Flag: Formal and Descriptive Representation of the Working Class in the Belgian House of Representatives 1946-2007. Labor History 53(2), 225-243. https://doi.org/10.1080/0023656X.2012.679398.

Wettstein M, Esser F, Schulz A, Wirz DS and Wirth W (2018) News Media as Gatekeepers, Critics, and Initiators of Populist Communication: How Journalists in Ten Countries Deal with the Populist Challenge. International Journal of Press/Politics 23(4), 476-495. https://doi.org/10.1177\%2F1940161218785979. 
Wihbey J, Coleman TD, Joseph K and Lazer D (2017) Exploring the Ideological Nature of Journalists' Social Networks on Twitter and Associations with News Story Content. Proceedings of Data Science + Journalism@ KDD'17, Halifax, Nova Scotia, Canada.

Wike P, Poushter J, Silver L, Devlin K, Fetteroff J, Castillo A and Huang C (2019) Gender Equality. Pew Research Center, 14 October. www.pewresearch.org/global/2019/10/14/gender-equality-2.

Wilson K (2020) Attitudes Toward LGBT People and Their Rights in Europe. Oxford Research Encyclopedia of Politics, 27 August. oxfordre.com/politics/view/10.1093/acrefore/9780190228637.001.0001/acrefore9780190228637-e-1335.

Wojcik S and Hughes A (2019) Sizing Up Twitter Users. Pew Research Center, 24 April. www.pewresearch. org/internet/2019/04/24/sizing-up-twitter-users.

Wondreys J and Mudde C (2021) Victims of the Pandemic? European Far-Right Parties and COVID-19. Nationalities Papers, forthcoming.

Wortman R (1967) The Crisis of Russian Populism. London: Cambridge University Press.

Ziblatt D (2017) Conservative Parties and the Birth of Democracy. New York: Cambridge University Press.

Cite this article: Mudde C (2021). Populism in Europe: An Illiberal Democratic Response to Undemocratic Liberalism (The Government and Opposition/Leonard Schapiro Lecture 2019). Government and Opposition: An International Journal of Comparative Politics 56, 577-597. https://doi.org/10.1017/gov.2021.15 